\title{
Effects of crude protein level in concentrate supplements on animal performance and nitrogen utilization of lactating dairy cows fed fresh-cut perennial grass
}

\author{
D. N. Hynes, ${ }^{*} \dagger$ S. Stergiadis, ${ }^{*} \ddagger$ A. Gordon, $\S$ and T. Yan ${ }^{* 1}$ \\ *Sustainable Agri-Food Sciences Division, Agriculture Branch, Agri-Food and Biosciences Institute, Large Park, Hillsborough, BT26 6DR, \\ United Kingdom \\ †Institute for Global Food Security, School of Biological Sciences, Queen's University Belfast, University Road, Belfast, BT7 1NN, United Kingdom \\ $\ddagger$ Animal, Dairy and Food Chain Sciences Division, Centre for Dairy Research, University of Reading, School of Agriculture, \\ Policy and Development, Reading, RG6 6AR, United Kingdom \\ §Finance and Corporate Affairs Division, Biometrics and Information Systems Branch, Agri-Food and Biosciences Institute, 18a Newforge Lane, \\ Belfast, BT9 5PX, United Kingdom
}

\begin{abstract}
Nitrogen pollution of air and ground water from grazing cattle is of increasing concern. Although several studies have investigated mitigation strategies for nitrogen output from dairy cows fed conserved forages and concentrates, similar research on fresh-cut grass in addition to production parameters is limited. The current study, using 3 dietary treatments and incorporating 2 genotypes, was designed to evaluate the effects of concentrate crude protein (CP) levels on animal production and nitrogen utilization efficiency (NUE) in lactating dairy cows. Twelve multiparous cows $(6$ Holstein and 6 Holstein $\times$ Swedish Red) were used in a changeover study with three 25 -d periods and 3 diet treatments. Low, medium and high $\mathrm{CP}$ concentrate $[14.1,16.1$, and $18.1 \%$, respectively, dry matter $(\mathrm{DM})$ basis] diets were fed at $32.8 \% \mathrm{DM}$ intake combined with good-quality zero-grazed perennial ryegrass $(18.2 \% \mathrm{CP}$, DM basis). Each period consisted of an adaptation phase (18 d) housed as a single group, a 1-d adaptation phase in individual stalls, and a 6 - $d$ measurement phase with feed intake and feces, urine, and milk output recorded. We observed no significant interaction between cow genotype and concentrate $\mathrm{CP}$ level on any animal performance or NUE parameter. Total DM intake, milk yield and composition, and NUE were not affected by dietary treatment. However, increasing concentrate CP level increased (1) $\mathrm{N}$ intake by $42 \mathrm{~g} / \mathrm{d}$ and excretion in urine and manure by 38 and $40 \mathrm{~g} / \mathrm{d}$, respectively, and (2) the ratio of urine $\mathrm{N}$ over manure N. Feeding high $\mathrm{CP}$ rather than low $\mathrm{CP}$ concentrate increased milk urea $\mathrm{N}(\mathrm{MUN})$ content by $3.6 \mathrm{mg} / \mathrm{dL}$ and total
\end{abstract}

Received February 29, 2016.

Accepted June 27, 2016.

${ }^{1}$ Corresponding author: tianhai.yan@afbini.gov.uk
MUN output by $1.08 \mathrm{~g} / \mathrm{d}$. Crossbred cows had lower grass DM intake, total DM intake, total $\mathrm{N}$ intake, and energy-corrected milk yield. However, cow genotype had no significant effect on NUE or MUN parameters. Equations have been developed to predict urine N excretion using MUN output as a sole predictor or in combination with dietary CP level. The present study indicated that when grazing cows are fed good-quality pasture, feeding concentrates with a protein content as low as $14.1 \%$ may not negatively affect productivity. In addition, reducing concentrate $\mathrm{CP}$ concentration may be successful in reducing the urinary $\mathrm{N}$ excretion of lactating dairy cattle on pasture-based systems, but further research is needed to investigate the long-term effects of supplementary concentrate $\mathrm{CP}$ content on milk production.

Key words: dairy cow, concentrate protein content, fresh grass, milk production, nitrogen utilization

\section{INTRODUCTION}

Greenhouse gas emissions from livestock production systems, specifically ruminants, are a major source of environmental concern. With normal bovine feeding practices, a large percentage of dietary protein is inefficiently used, leading to increased manure $\mathrm{N}$ output and resulting environmental, health (Butler, 1998), and economic implications. Excess $\mathrm{N}$ excretion from ruminants can be converted to many forms, such as ammonia, a major air pollutant; $\mathrm{N}_{2} \mathrm{O}$, a greenhouse gas; and nitrate, a water pollutant. The considerable variation in levels of $\mathrm{N}$ excretion in urine across a range of dietary treatments highlights the potential for alleviation (Castillo et al., 2000). Grasslands are the most economical feedstuff for dairy farmers in Northern and Western Europe (Peyraud and Delagarde, 2013). However, because controlling forage nutrient composition can prove difficult, 
a feasible mitigation option for improving nitrogen utilization efficiency (NUE) may be to reduce the CP content in concentrate feeds. This may be possible in pasture-based systems as opposed to indoor systems on silage-based diets because pasture often possesses a CP content in excess of or close to $20 \%$ on a DM basis (Kavanagh et al., 2003), a value considerably greater than that typically found in conserved forage. Hence, it is vital that $\mathrm{N}$ partitioning be assessed in all commonly used farming practices to reduce pollution and maintain herd health in a cost-effective manner across dairy production systems. Previous studies have shown improved NUE, in particular reduced urinary $\mathrm{N}$ excretion, as a result of reduced concentrate CP levels (Castillo et al., 2000; Marini and Van Amburgh, 2005; Burke et al., 2008). However, whether improved NUE and N partitioning, in addition to production responses, can be achieved using low $\mathrm{CP}$ concentrates in a fresh-cut grass-based diet has not yet been determined.

Evidence also points to a genetic effect on $\mathrm{N}$ metabolism (Pareek et al., 2007; Beecher et al., 2014), although to a lesser extent than dietary $\mathrm{CP}$ content (Huhtanen et al., 2015). It is well documented that MUN is used to monitor feed management practice, specifically excess dietary $\mathrm{CP}$, and has been suggested as an indicator for urinary $\mathrm{N}$ excretion (Jonker et al., 1998; Kauffman and St-Pierre, 2001). Previous literature has found the relationship between urinary $\mathrm{N}$ and MUN concentration may be subject to genetic influence (Kauffman and St-Pierre, 2001), with significant differences found between Holstein and Jersey cows. Some of this variation may be explained by milk yield and BW (Huhtanen et al., 2015) or as a result of genetic variation in urea transporters in the kidney and across the rumen epithelium, with different alleles resulting in increased or reduced activity (Aguilar et al., 2012). Conversely, some trials found no evidence of a genetic effect on N utilization (Zou et al., 2016) or MUN concentration (Carlsson et al., 1995). Swedish Red is a high-producing breed in common use in Northern Europe that has been crossed with Holsteins to improve fertility, udder health, and longevity (Heins and Hansen, 2012), resulting in greater projected lifetime profit and profit per cow-day than the Holstein breed (Heins et al., 2012). Because Holstein and Swedish Red represent important bovine breeds for milk yield and solids output, a comparison between Holstein and Holstein $x$ Swedish Red crossbreds would be suitable for examining the genetic and physiological effects on variation of $\mathrm{N}$ partitioning in dairy cattle.

The objective of the present study was (1) to investigate the effects of animal genetics and varying concentrate $\mathrm{CP}$ content on milk production levels in combination with NUE and N partitioning parameters and (2) to develop linear and multiple relationships to estimate MUN and urinary $\mathrm{N}$ outputs for lactating dairy cows on similar diets to those offered in the present study using readily available data at the farm level.

\section{MATERIALS AND METHODS}

All animal procedures in the present study were conducted under experimental license from the Department of Health, Social Services and Public Safety of Northern Ireland in accordance with the Animal (Scientific Procedures) Act (Home Office, 1986).

\section{Experimental Design}

The current study was conducted during the 2014 grazing season at Agri-Food and Biosciences Institute (Hillsborough, Northern Ireland, UK), using 6 pure Holstein and 6 crossbred (50:50 Holstein $\times$ Swedish Red) cows fed fresh-cut grass and 3 differing concentrate feeds in a 3-period (25 d/period) changeover design study. Cows from each genotype were blocked into 3 groups of 2 cows based on milk yield, BW, and lactation stage, and were then randomly allocated to one of the 3 dietary treatments. The mean milk yield, BW, and DIM at the start of the trial were $26 \pm 4.9 \mathrm{~kg} / \mathrm{d}$, $550 \pm 39.9 \mathrm{~kg}$, and $119 \pm 20.5 \mathrm{~d}$, respectively. The diet treatments were a low CP concentrate (LCP, 14.1\%), a medium CP concentrate (MCP, 16.1\%) and a high CP concentrate (HCP, 18.1\%) on a DM basis offered at $35 \%$ DMI, in combination with fresh-cut perennial ryegrass offered at $65 \%$ DMI. Each experimental period consisted of (1) an initial 18-d feed adaptation phase, where cows were housed as a single group with individual feed intake recorded; (2) a 1-d adaptation phase in individual stalls; and (3) a 6-d digestibility unit phase, with daily recording of feed intake and total collection of feces, urine, and milk outputs.

The LCP and HCP concentrates were formulated separately; both contained the same feed ingredients and similar chemical composition (with the exception of $\mathrm{CP}$ content). The MCP concentrate was then produced by mixing the LCP and HCP concentrates in a 1:1 (wt/wt) ratio. The ingredients and chemical composition of LCP and HCP concentrates are presented in Tables 1 and 2, respectively. Half of the daily concentrate rations were offered at morning milking $(0700 \mathrm{~h})$ and half at afternoon milking $(1500 \mathrm{~h})$, and fresh-cut grass, harvested with a Haldrup 1500 (Plot Combine, Haldrup, Ilshofen, Germany) from a single sward, was offered at $1000 \mathrm{~h}$ each morning ad libitum. Herbage received a primary cut in April 2014 and was subsequently harvested at regrowth intervals according to month (increasing from 22 to $30 \mathrm{~d}$ from June to Sep- 
Table 1. Concentrate ingredient composition $\left(\mathrm{g} / \mathrm{kg}\right.$ of DM) ${ }^{1}$

\begin{tabular}{|c|c|c|}
\hline Ingredient & $\mathrm{LCP}$ & $\mathrm{HCP}$ \\
\hline Corn & 246 & 220 \\
\hline Wheat feed & 140 & 135 \\
\hline Corn gluten & 140 & 135 \\
\hline Soy hulls & 140 & 135 \\
\hline Palm kernel expeller & 110 & 110 \\
\hline Sugar beet pulp & 45 & 0 \\
\hline Sunflower kernel & 66 & 60 \\
\hline Soybean meal & 0 & 80 \\
\hline Rapeseed extract & 0 & 27 \\
\hline Molaferm & 70 & 50 \\
\hline Pure palm oil & 7 & 7 \\
\hline Limestone flour & 14 & 19 \\
\hline Salt & 8.5 & 9.4 \\
\hline Calcined magnesite & 8.8 & 8.6 \\
\hline Trace elements and vitamins ${ }^{2}$ & 4.0 & 4.0 \\
\hline \multicolumn{3}{|c|}{$\begin{array}{l}{ }^{1} \mathrm{LCP}=\text { low } \mathrm{CP} \text { concentrate }(14.1 \%, \mathrm{DM} \text { basis }) ; \mathrm{HCP}=\text { high } \mathrm{CP} \text { col } \\
\text { centrate }(18.1 \% \text {, DM basis }) .\end{array}$} \\
\hline \multicolumn{3}{|c|}{$\begin{array}{l}{ }^{2} \text { Trace elements and vitamins consisted of } 25 \mathrm{IU} / \mathrm{kg} \text { of vitamin E, } \\
\mathrm{mg} / \mathrm{kg} \text { of I, } 0.6 \mathrm{mg} / \mathrm{kg} \text { of } \mathrm{Se}, 30 \mathrm{mg} / \mathrm{kg} \text { of } \mathrm{Cu}, 50 \mathrm{mg} / \mathrm{kg} \text { of } \mathrm{Mn} \text {, an } \\
100 \mathrm{mg} / \mathrm{kg} \text { of } \mathrm{Zn}, 9,000 \mathrm{IU} / \mathrm{kg} \text { of vitamin } \mathrm{A} \text {, and } 2,000 \mathrm{IU} / \mathrm{kg} \text { of v } \\
\text { tamin } \mathrm{D}_{3} \text {. }\end{array}$} \\
\hline
\end{tabular}

tember), generating grass of a similar quality to that under commercial management. Grass in the sward consisted of a 3-yr re-seed of 'Aberstar', 'Aberzest', and 'Alice' varieties, sown in a ratio of 8:5:1, respectively, and paddocks had not been grazed since the end of the previous grazing season (November 2013). Postharvesting fertilization was implemented within $3 \mathrm{~d}$ at $35 \mathrm{~kg}$ of $\mathrm{N} / \mathrm{ha}$. The temperature of the fresh-cut grass was monitored throughout the study to minimize the risk of nutrient degradation by plant proteases (Callis, 1995). Animals had free access to water throughout the experiment. Concentrate offered was calculated for individual animals as 35\% total DMI using the previous 7-d running average of ad libitum forage intake.

\section{Measurements}

Body weight was recorded before and after the digestibility unit phase. Daily herbage intakes and re- fusals were recorded, sampled, and analyzed for oven $\mathrm{DM}$ at $85^{\circ} \mathrm{C}$ during the 6 - $\mathrm{d}$ measurement phase at the end of each period. Fresh herbage samples were dried in an oven at $60^{\circ} \mathrm{C}$ for $72 \mathrm{~h}$ (Ruiz et al., 2001; Jiao et al., 2014), milled through a $0.8-\mathrm{mm}$ screen and analyzed for ADF, NDF, ash, gross energy (GE), N, and water-soluble carbohydrates (WSC) content on a daily basis. Concentrate samples (200 g) were taken 4 times per week and dried for $48 \mathrm{~h}$ at $100^{\circ} \mathrm{C}$ according to AOAC (1980; official method 14.063). Samples were then composited, milled through a $0.8-\mathrm{mm}$ screen, and analyzed for weekly determination of DM, ADF, NDF, ash, GE, starch, and N concentrations. Feces and urine outputs were weighed, recorded, and sampled separately as a percentage (5\%) of total fecal output (by weight) and urine output (by volume) for the 6-d collection phase in the digestibility units. Daily urine and fecal samples were stored at $4^{\circ} \mathrm{C}$ after collection, and 3-d samples were pooled for analysis. Samples were thoroughly mixed, and a representative sample was obtained for fresh analysis of $\mathrm{N}$ content for feces and urine, according to the method in Jiao et al. (2013). A subsample of the bulked 3-d feces samples was dried at $85^{\circ} \mathrm{C}$ for subsequent DM, ADF, NDF, and ash analysis, as described by Cushnahan and Gordon (1995). To prevent ammonia volatilization from urine samples during the 24-h collection, sulfuric acid solution $\left(50 \% \mathrm{H}_{2} \mathrm{SO}_{4}\right)$ was added to the urine canisters before collection to achieve a $\mathrm{pH}$ between 2.0 and 4.0 (Freudenberger et al., 1994). Milk samples of $2 \%$ volume were collected twice daily, bulked for 3 -d phases, and frozen $\left(-20^{\circ} \mathrm{C}\right)$ until analysis. Milk samples were analyzed by Milkoscan (Foss Electric, Hillerød, Denmark) for fat, protein, and lactose. Contents of MUN were measured using the QuantiChrom urea assay kit (DIUR-500) after a deproteination step (BioAssay Systems, Hayward, CA). Analysis of milk GE was performed according to the method described by Jiao et al. (2013). Determination of GE, N (grass and concentrate only), and ash was performed as described previously by Cushnahan and

Table 2. Chemical composition $(\mathrm{g} / \mathrm{kg}$ of $\mathrm{DM}$, unless otherwise stated) of dietary components used in the present experiment

\begin{tabular}{|c|c|c|c|c|c|}
\hline \multirow[b]{2}{*}{ Component } & \multicolumn{3}{|c|}{ Grass } & \multicolumn{2}{|c|}{ Concentrate $^{1}$} \\
\hline & July & August & September & $\mathrm{LCP}$ & $\mathrm{HCP}$ \\
\hline $\mathrm{DM}(\mathrm{g} / \mathrm{kg})$ & 154 & 147 & 161 & 898 & 898 \\
\hline Ash & 100 & 94 & 94 & 89 & 91 \\
\hline $\mathrm{CP}$ & 18.8 & 17.8 & 18.3 & 14.1 & 18.1 \\
\hline Gross energy (MJ/kg of DM) & 18.7 & 18.7 & 18.4 & 18.0 & 18.1 \\
\hline $\mathrm{NDF}$ & 490 & 454 & 440 & 369 & 369 \\
\hline $\mathrm{ADF}$ & 239 & 234 & 222 & 189 & 187 \\
\hline Starch & - & - & - & 232 & 211 \\
\hline Water-soluble carbohydrates & 130 & 171 & 184 & - & - \\
\hline
\end{tabular}

${ }^{1} \mathrm{LCP}=$ low $\mathrm{CP}$ concentrate (14.1\%, DM basis); HCP = high CP concentrate (18.1\%, DM basis). 
Gordon (1995). For analysis of grass, concentrate, and milk concentrations of GE a Parr 6300 oxygen bomb calorimeter (Parr Instrument Company, Moline, IL) was used. Total $\mathrm{N}$ content was determined on a DM basis for grass and concentrate, and on a fresh basis for feces and urine, using a Vario Max CN (Elementar, Hanau, Germany) and a Kjeltec 2400 analyzer (Foss Tecator AB, Höganäs, Sweden), respectively. Ash in grass, concentrate, and feces was determined by incineration in a muffle furnace (Vecstar, Derbyshire, $\mathrm{UK})$ at $550^{\circ} \mathrm{C}$ for approximately $10 \mathrm{~h}$ (AOAC, 1990). Ash-corrected concentrations of ADF and NDF were determined sequentially using a Fibertec fiber analyzer (Foss Electric, Hillerød, Denmark). The NDF was assayed using sodium sulfite and $\alpha$-amylase, as described by Van Soest et al. (1991). The total starch content of concentrate was measured using a total starch assay kit (Megazyme International Ireland Ltd., Wicklow, Ireland; McCleary et al., 1994). The WSC content of grass was determined spectrophotometrically using anthrone in sulfuric acid and the Technicon Autoanalyzer (Technicon Corp., New York, NY; Thomas, 1977).

\section{Statistical Analysis}

Energy-corrected milk yield was calculated as milk energy output (milk yield multiplied by measured milk energy concentration) divided by milk energy content in $1 \mathrm{~kg}$ of standard milk $(40 \mathrm{~g} / \mathrm{kg}$ fat, $32 \mathrm{~g} / \mathrm{kg}$ protein, and $48 \mathrm{~g} / \mathrm{kg}$ lactose) using the equation of Tyrrell and Reid (1965). Experimental data were analyzed using the Genstat statistical package (VSN International, 2013). All variables were analyzed using the linear mixed model methodology with REML estimation (Gilmour et al., 1995). In the analysis, which was based on individual animal data, cow and date (of entry to collection phase) were fitted as random effects, and genotype and treatment as fixed effects. Orthogonal polynomial contrasts (linear and quadratic) were used to examine treatment effect on response variables. The significance of fixed effects was assessed by comparing an F-statistic against an F-distribution. Residuals showed no deviation from normality. The differences between treatments, genotypes, and interactions were assessed and declared as nonsignificant at $P>0.05$ and significant at $P<0.05, P<0.01$, and $P<0.001$. A REML analysis was also performed to develop a range of linear and multiple relationships to estimate MUN and urine $\mathrm{N}$ outputs using the method previously described by Stergiadis et al. (2015). In brief, linear regression relationships were developed where the responses were MUN output, MUN concentration, and urine N output, and the explanatory variables were $\mathrm{N}$ intake, dietary CP content, and MUN output, respectively. A multiple linear regression was also developed to predict urine $\mathrm{N}$ output using MUN and dietary CP content as explanatory variables. The potential random effects of cow and date of entry were removed in all equations. The Wald statistic was used to evaluate the significance of the fixed terms. For all equations, a pseudo- $\mathrm{R}^{2}$ was also generated, which describes the squared correlation of the response and the fitted values, to represent the amount of variability explained.

\section{RESULTS}

The effect of the main factors was significant on several feed/nutrient intake, production, and NUE parameters, but we observed no significant interaction between cow genotype and dietary treatment. Focus in the results and discussion sections will be on main treatment effects.

\section{Diet Composition}

The chemical composition of individual dietary components is given in Table 2. Grass NDF and ADF content both decreased and WSC content increased from July to September; but we observed no seasonal variation for ash, $\mathrm{CP}$, or $\mathrm{GE}$ contents of grass. The perennial ryegrass offered in the present experiment contained an average DM of $154 \mathrm{~g} / \mathrm{kg}$; GE of $18.6 \mathrm{MJ} /$ $\mathrm{kg} \mathrm{DM}$; CP of $18.2 \% \mathrm{DM}$; and 95.4, 456, 231, and 167 $\mathrm{g} / \mathrm{kg}$ DM for ash, NDF, ADF, and WSC respectively. The chemical composition of the 3 concentrates was very similar, except for the $\mathrm{CP}$ content, which resulted in total dietary CP levels for the LCP, MCP, and HCP diets of $16.9,17.6$, and $18.3 \% \mathrm{DM}$, respectively.

\section{Feed Intake and Milk Production}

The effects of concentrate CP contents and cow genotype on feed intake and animal characteristics and production parameters are displayed in Table 3. On average, animal diets were composed of (DM basis) $67.2 \%$ fresh grass and $32.8 \%$ concentrate feed. Concentrate CP levels had no significant effect on voluntary feed intake or on milk production and composition. In contrast, cow genotype had significant effect on feed intake, animal characteristics, and milk production and composition parameters. Holstein cows had significantly higher grass intake $(+6.7 \%)$ and DMI $(+5.4 \%)$ than crossbred cows. Holstein cows produced significantly higher yields of ECM $(3.6 \mathrm{~kg} / \mathrm{d}$ or $+14.1 \%)$ and had significantly higher milk lactose content $(+3.4 \%)$ but lower milk protein content $(-10.5 \%)$. 


\section{N Partitioning and Utilization}

The effects of concentrate CP content and cow genotype on $\mathrm{N}$ intake, outputs, and utilization variables are displayed in Table 4. Intake of total and digestible $\mathrm{N}$ increased linearly with increasing concentrate $\mathrm{CP}$ content. Cows fed the HCP diet consumed $42 \mathrm{~g} / \mathrm{d}$ more total $\mathrm{N}$ ) and $37 \mathrm{~g} / \mathrm{d}$ more digestible $\mathrm{N}$ than cows fed the LCP diet. Feeding LCP concentrate significantly and linearly reduced urine $\mathrm{N}$ excretion compared with feeding $\mathrm{HCP}$ concentrate $(-38 \mathrm{~g} / \mathrm{d})$. Excretion of manure $\mathrm{N}$ increased linearly with increasing concentrate $\mathrm{CP}$ content $(+40 \mathrm{~g} / \mathrm{d}$ for cows fed the HCP diet compared with those fed the LCP diet). Dietary treatment exerted no significant effect on $\mathrm{N}$ outputs in feces or milk, retained N, and several NUE parameters (proportion of $\mathrm{N}$ intake excreted in feces, urine, manure, milk, and the ratio of retained to digested $\mathrm{N}$ ). In fact, we observed a shift in $\mathrm{N}$ excretion from urine to feces when expressed relative to manure $\mathrm{N}$; the proportion of urine $\mathrm{N}$ was significantly decreased and the proportion of feces $\mathrm{N}$ was significantly increased in cows fed the LCP diet compared with cows fed the HCP diet.

Compared with crossbred cows, Holstein cows had significantly higher intakes of total $\mathrm{N}(+25 \mathrm{~g} / \mathrm{d})$ and digestible $\mathrm{N}(+19 \mathrm{~g} / \mathrm{d})$, but genotype had no significant effect on any NUE variable.

\section{MUN Output}

Milk urea $\mathrm{N}$ output values are shown in Table 5 . We found that MUN output increased linearly with increasing concentrate $\mathrm{CP}$ content, so that MUN values in cows fed the HCP diet were on average $1.08 \mathrm{~g} / \mathrm{d}$ higher than cows fed the LCP diet. We also found that MUN concentrations declined linearly with decreasing concentrate $\mathrm{CP}$ content $(-1.6$ and $-3.6 \mathrm{mg} / \mathrm{dL}$ for cows offered MCP and LCP compared with HCP diets, respectively). However, concentrate $\mathrm{CP}$ level had no significant effect on MUN output when expressed as a proportion of total $\mathrm{N}$ intake or digestible $\mathrm{N}$ intake. The effect of cow genotype on MUN excretion, concentration, or proportion to total $\mathrm{N}$ or digestible $\mathrm{N}$ intakes was not significant.

\section{Estimation of MUN and Urine N Output}

When linear and multiple relationships for estimating urine $\mathrm{N}$ output and MUN output and concentration were developed, the explained variation was higher for prediction of MUN parameters (Table 6). The effect of (1) N intake and dietary CP content for the prediction of MUN output and MUN concentrations, respectively, and (2) MUN and dietary CP content for the prediction 

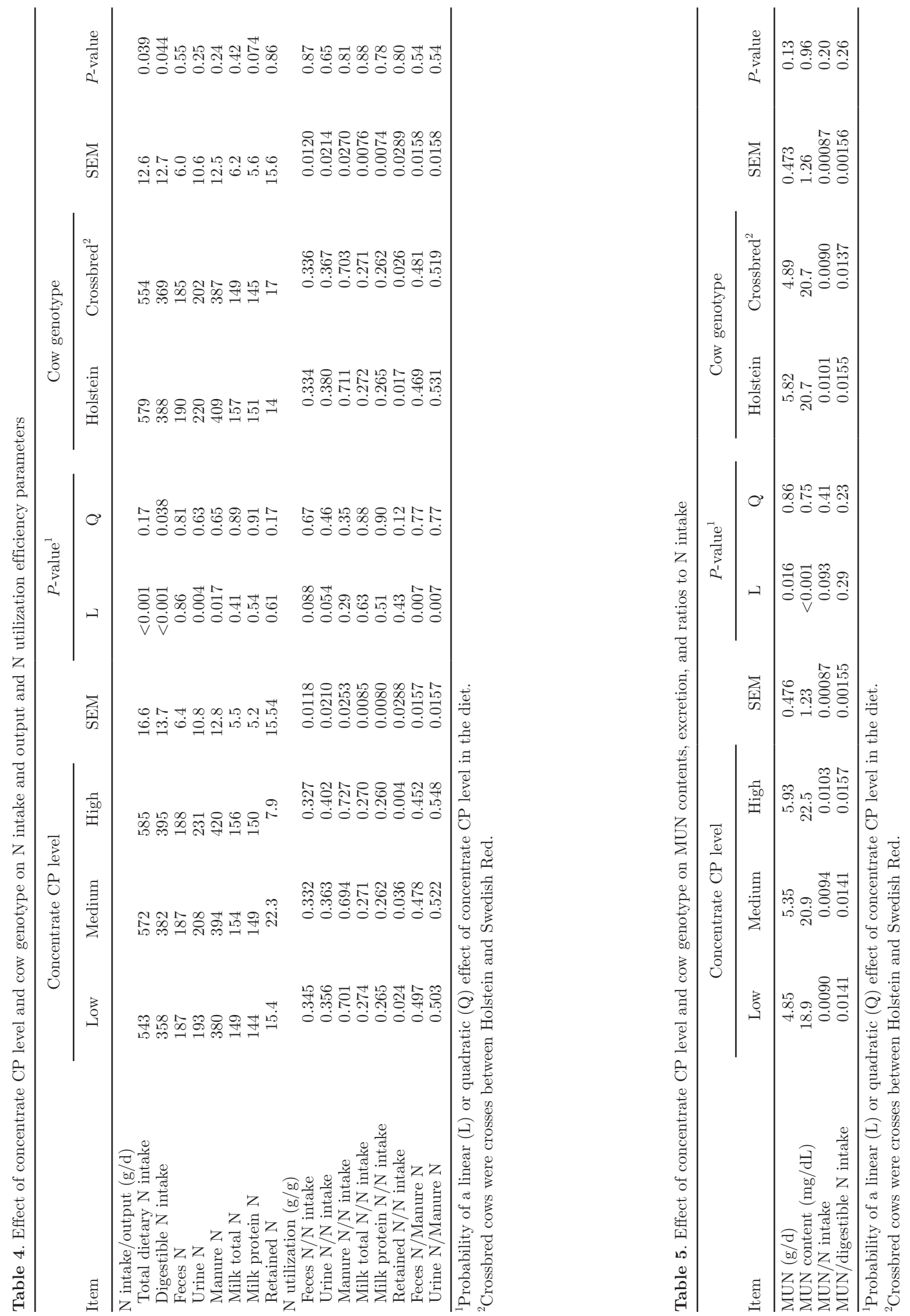


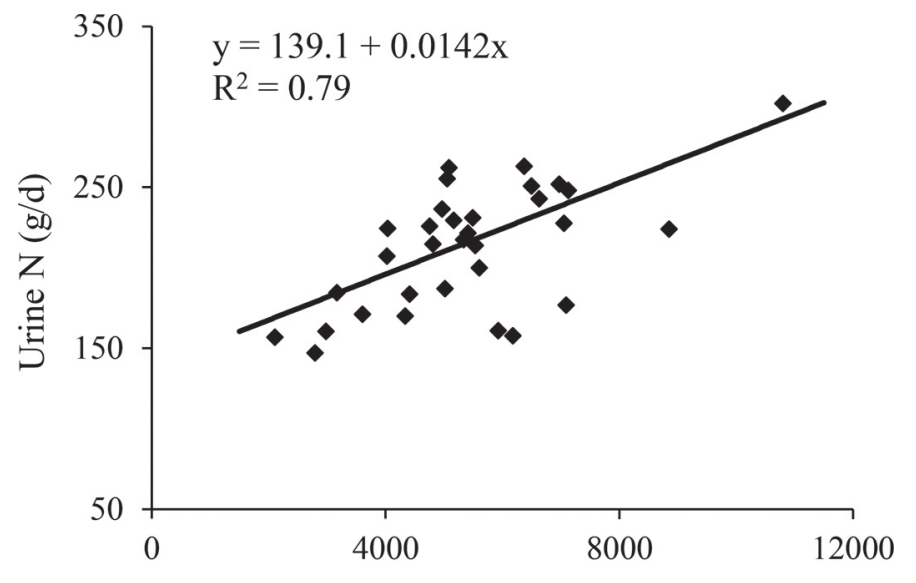

Milk urea $\mathrm{N}(\mathrm{mg} / \mathrm{d})$

Figure 1. Relationship between MUN and urine N output for lactating dairy cows on diets of 2:1 fresh grass:concentrate ratio, as presented in equation [3] in Table 6.

of urine $\mathrm{N}$ output, were significant according to the Wald statistic, and all relations were positive. Figure 1 displays the positive relationship between urine $\mathrm{N}$ output $(\mathrm{g} / \mathrm{d})$ and MUN output $(\mathrm{mg} / \mathrm{d})$, as shown in equation [3] in Table 6.

\section{DISCUSSION}

The manipulation of concentrate $\mathrm{CP}$ concentration is commonly used to optimize rumen microbial activity and milk production for grazing and confined dairy production systems. Responses in NUE have been extensively evaluated in confined dairy cows offered grass silage, but such information may not be accurate for grazing cows, as the ensiling process can considerably alter the nutritive value of forage. Increases in the $\mathrm{CP}$ fraction $\mathrm{A}(\mathrm{NPN})$ at the expense of $\mathrm{CP}$ fraction $\mathrm{B}$ (true protein), rate of proteolysis, and VFA concentrations, as well as reductions in carbohydrate content, occur during ensiling. In addition, daily deviations in pasture $\mathrm{CP}$ content are more pronounced compared with conserved forage, which may also affect the ruminal protein-energy balance. The present study was designed to evaluate the effects of manipulation of concentrate $\mathrm{CP}$ concentration on milk production and NUE of dairy cows offered fresh grass.

\section{Diet Composition}

Ryegrass used in the present study was typical for good-quality ryegrass (Ministry of Agriculture, Fisheries and Food, 1992). The WSC content of the fresh-cut grass increased between July and September, possibly due to longer grass regrowth intervals toward the end of the grazing season (Owens et al., 2008). Throughout the present experiment, good-quality ryegrass was offered, averaging $18.2 \% \mathrm{CP}, 461 \mathrm{~g} / \mathrm{kg}$ of NDF, and 162 $\mathrm{g} / \mathrm{kg}$ of WSC. Consequently, animals consumed higher than expected levels of fresh grass in the measurement periods, leading to a marginally higher dietary forage proportion than the designed level $(67.2 \%$ vs. $65 \% \mathrm{DM}$ basis). These 2 factors in combination may have reduced the extent of the responses between treatments for some of the parameters.

\section{Production Performance}

Although concentrate feed was designed to be $35 \%$ DMI, the actual concentrate intake was $32.8 \%$ of total DMI due to the higher grass DMI $(14.0 \mathrm{~kg} / \mathrm{d})$ in the digestibility units than in the housing cubicles (12.6 $\mathrm{kg} / \mathrm{d}$ ). The concentrate feed proportion was chosen to be representative of commercial practice in the UK (Ferris, 2007) and to be of a sufficient level to achieve significant differences in total dietary $\mathrm{CP}$ content across treatments. The results from the present study implied that feeding a concentrate of $14.1 \% \mathrm{CP}$ when goodquality perennial ryegrass is grazed might sustain milk yield and milk quality in pasture-based systems. Previous studies found that offering concentrate of $15 \% \mathrm{CP}$ to supplement grazing was associated with a decrease in milk yield of $2.9 \mathrm{~kg} / \mathrm{d}$ compared with feeding a $19 \%$ CP concentrate (Whelan et al., 2012); low-protein diets (14-16\% CP) also decreased production and tended to decrease milk protein content in corn and grass-clover silage-based diets (Alstrup et al., 2014). More recent studies have shown that concentrates with $\mathrm{CP}$ content

Table 6. Regression models for the prediction of MUN and urine $\mathrm{N}$ excreta from lactating dairy cows

\begin{tabular}{llllll}
\hline $\begin{array}{l}\text { Equation } \\
\text { no. }\end{array}$ & Equation $^{1}$ & & & \\
\hline 1 & MUN output $(\mathrm{g} / \mathrm{d})$ & $=$ & $-3.1_{(2.69)}+0.015_{(0.0047)} \mathrm{N}$ intake $(\mathrm{g} / \mathrm{d})$ & \\
2 & MUN content $(\mathrm{mg} / \mathrm{dL})$ & $=$ & $-31.3_{(8.64)}+0.295_{(0.0486)} \operatorname{diet} \mathrm{CP}$ content $(\mathrm{g} / \mathrm{kg}$ of DM) & 0.946 \\
3 & Urine N output (g/d) & $=139.1_{(18.07)}+0.0142_{(0.00316)} \mathrm{MUN}(\mathrm{mg} / \mathrm{d})$ & 0.975 \\
4 & Urine N output $(\mathrm{g} / \mathrm{d})$ & $=$ & $-144.4_{(72.32)}+0.010_{(0.0028)} \mathrm{MUN}(\mathrm{mg} / \mathrm{d})+1.74_{(0.432)} \operatorname{diet~CP~content~}(\mathrm{g} / \mathrm{kg})$ & 0.792 \\
\hline
\end{tabular}

${ }^{1}$ Values in subscript parentheses represent standard errors. The effects of all explanatory variables were significant according to the Wald statistic $(P<0.05)$. The potential random effects of cow and date were removed for all predicted variables. 
as low as $14 \%$ might be fed to dairy cows without negative implications for milk production (Sinclair et al., 2014). A range of diet and animal factors could influence the effect of concentrate CP levels on the milk production of grazing cows, including milk production potential, stage of lactation, and forage quality (Moran, 2005; De Oliveira et al., 2010). In the present study, the high milk protein content observed across all treatments is generally considered indicative of a high-energy diet (Broderick, 2003), which may have been a result of the quality of grass offered. The results of the present study indicate that dairy cows grazing good-quality pasture can be offered low CP concentrates, resulting in a total dietary CP content of $16.9 \%$ DM with no negative effect on feed intake or milk production.

\section{N Partitioning and Utilization}

We observed that increasing concentrate $\mathrm{CP}$ levels in a predominantly fresh ryegrass diet supplemented with concentrate increased total intake of $\mathrm{N}$ and digestible N. Feces N values were less variable (144-246 g/d) than urine $\mathrm{N}$ values $(112-302 \mathrm{~g} / \mathrm{d})$, and this result was similar to those observed in the literature (Ruiz et al., 2001; Lee et al., 2009; Kebreab et al., 2010). In the present study, the nonsignificant effect of concentrate $\mathrm{CP}$ concentration on feces $\mathrm{N}$ excretion was partially due to similar DMI between treatments, an influential factor in fecal $\mathrm{N}$ output. This finding may also indicate that the ammonia-N supply from the LCP diet was enough to meet the requirement of rumen microbial growth, and the excess supply of degradable $\mathrm{N}$ in the $\mathrm{MCP}$ or HCP diet was excreted in urine as urea. Indeed, we found that urine $\mathrm{N}$ outputs were significantly higher with the HCP diet. Compared with the LCP diet, the additional $\mathrm{N}$ intake in the HCP diet $(42 \mathrm{~g} / \mathrm{d}$ ) was almost entirely excreted in urine $(38 \mathrm{~g} / \mathrm{d})$, demonstrating the sensitivity of the correlation between urinary $\mathrm{N}$ excretion and supplementary concentrate N. Broderick and Reynal (2009) observed an increase of $96 \mathrm{~g} / \mathrm{d}$ in urine $\mathrm{N}$ excretion associated with an increase in dietary CP intake from 15.1 to $18.4 \%$, attributed mostly to an increase of urinary urea N. Furthermore, findings from a meta-analysis on growing cattle offered a CP supplement indicated that up to $90 \%$ of incremental $\mathrm{N}$ intake that exceeds the requirement of rumen microbial activity is partitioned into urine (Huuskonen et al., 2014). This was in agreement with results from the present study, in which $38 \mathrm{~g} / \mathrm{d}$ of the $42 \mathrm{~g} / \mathrm{d}$ incremental CP was excreted as urinary $\mathrm{N}$, a figure close to the predicted value of $37.8 \mathrm{~g} / \mathrm{d}$. Our results showed that feeding low-protein concentrates $(14.1 \%$ $\mathrm{CP})$ may serve as a mitigation strategy for reducing urine $\mathrm{N}$ output for cows consuming fresh-cut grass and concentrate diets, reducing environmental footprint $\left(\mathrm{N}_{2} \mathrm{O}\right.$ emissions, nitrate and ammonia pollution) from pasture-based systems. Reducing the CP concentration of ruminant diets has been recommended as the most effective method of reducing $\mathrm{N}_{2} \mathrm{O}$ emissions from dairy farms; it was estimated to cause a 7 -fold improvement in mitigation efficiency compared with alleviating $\mathrm{N}_{2} \mathrm{O}$ emissions through manure storage and management (Marini and Van Amburgh, 2005).

Our work showed that feeding low CP concentrates in a fresh-cut grass-based diet could shift $\mathrm{N}$ excretion from urine to feces when expressed as a proportion of manure N output. Regarding environmental concerns associated with grazing livestock, the shift of $\mathrm{N}$ excretion is desirable because $\mathrm{N}$ in feces is less volatile than in urine and may be converted to ammonia and $\mathrm{N}_{2} \mathrm{O}$ at a slower rate (Van der Weerden et al., 2011). This is because fecal $\mathrm{N}$ is for the most part organically bound, composed mainly of microbial and endogenous $\mathrm{N}$ with some undigested feed N (Ellis et al., 2011), which must first undergo mineralization; urinary $\mathrm{N}$ is primarily in the form of urea, which is rapidly hydrolyzed to ammonium (Beukes et al., 2011).

Pure and crossbred Holstein cows showed similar NUE, in line with Huhtanen et al. (2008), who suggested dietary components may have a greater influence on milk protein $\mathrm{N}$ efficiency than level of production, although it also plays a role.

\section{Development of Regression Equations Estimating Urine N Excretion for Grazing Dairy Cows}

Previous work has shown that MUN concentration and urine $\mathrm{N}$ output are positively associated with dietary CP level, most likely a result of increased BUN (Jonker and Kohn, 2001; Huhtanen et al., 2015); therefore, MUN has been suggested as a noninvasive indicator for urine N excretion (Jonker and Kohn, 2001). Concentration of MUN is highly related to dietary $\mathrm{CP}$ content, and measurement is common practice in the dairy industry. However, differences exist between regression equations presented in the current study (equation [2], Table 6) and in previous studies, in which prediction equations were developed with animals fed diets based on conserved forage (Nousiainen et al., 2004; Spek et al., 2013). These differences may be a result of a combination of factors, such as animal diets, stage of lactation, genetic merit, and analytical techniques. Regression equations developed in the current study showed that urinary $\mathrm{N}$ output is positively related to MUN output and dietary CP content, which can be used as readily available predictors in practice. Positive relations between urine $\mathrm{N}$ output and MUN concentration have been found previously and explained by 
the small neutral nature of a urea molecule, allowing MUN to equilibrate with BUN via diffusion into and out of the mammary gland (Jonker and Kohn, 2001). Spek et al. (2013) also found that urine N outputs' best sole predictors were feed CP content and MUN content. The fact that addition of dietary $\mathrm{CP}$ content to MUN content as predictors of urine $\mathrm{N}$ output only slightly improved $\mathrm{R}^{2}$ in the present study implies that in practice the use of dietary $\mathrm{CP}$ content can be omitted without substantial compromise of prediction accuracy, when only routinely collected farm-level MUN content data are available. This allows for readily available, relatively reliable and inexpensive estimations of urine $\mathrm{N}$ excretions in pasture-based systems. The model we developed predicted urine $\mathrm{N}$ excretion to increase by $14.2 \mathrm{~g} / \mathrm{d}$ with an increase of $1 \mathrm{~g}$ in MUN secreted, within the range of MUN values measured in the current study.

Mitigating NUE in dairy cattle requires reducing urinary $\mathrm{N}$ output without compromising - and preferably increasing - milk protein $\mathrm{N}$ yields. Because the majority of milk $\mathrm{N}$ is presented as protein, and protein yields depend on energy supplies, optimizing dietary energy supply but offering minimal levels of dietary CP without reducing productivity and milk solid concentrations would show high potential for mitigating $\mathrm{N}$ outputs in pasture-based systems.

\section{CONCLUSIONS}

The current results suggest urine $\mathrm{N}$ excretion from grazing lactating dairy animals can be alleviated by offering a concentrate with a CP level of $14.1 \%$ DM when good-quality perennial ryegrass is consumed. This practice can also reduce urine $\mathrm{N}$ as a proportion of total $\mathrm{N}$ excretion, which is considered environmentally desirable, because it decreases the volatilization of nitrogenous compounds, including $\mathrm{N}_{2} \mathrm{O}$ emissions. Feeding the low $\mathrm{CP}$ concentrate did not affect voluntary grass intake, total intake, or production traits, implying that the proposed mitigation strategy should not compromise the economic performance of the dairy farm, although sustainability of production would have to be confirmed in a long-term study. The linear and multiple relationships developed in the current study may assist in the estimation of urine $\mathrm{N}$ output from animals fed fresh grass and concentrate diets, using readily available data at a commercial level, such as MUN data in conjunction with feed chemical composition or not.

\section{ACKNOWLEDGMENTS}

This study was funded by the Department of Agriculture, Food and the Marine of Republic of Ireland
(Dublin) as part of the Stimulus-funded project. Technical assistance from staff of the Agri-Food and Biosciences Institute Hillsborough Energy Metabolism Unit and laboratory, as well as Melanie Robert, is gratefully acknowledged.

\section{REFERENCES}

Aguilar, M., M. D. Hanigan, H. A. Tucker, B. L. Jones, S. K. Garbade, M. L. McGilliard, C. C. Stallings, K. F. Knowlton, and R. E. James. 2012. Cow and herd variation in milk urea nitrogen concentrations in lactating dairy cattle. J. Dairy Sci. 95:7261-7268.

Alstrup, L., M. R. Weisbjerg, L. Hymoller, M. K. Larsen, P. Lund, and M. O. Nielsen. 2014. Milk production response to varying protein supply is independent of forage digestibility in dairy cows. J. Dairy Sci. 97:4412-4422.

AOAC. 1980. Official Methods of Analysis. 13th ed. Association of Official Analytical Chemists, Washington, DC.

AOAC. 1990. Official Methods of Analysis. 15th ed. Association of Official Analytical Chemists, Arlington, VA.

Beecher, M., F. Buckley, S. M. Waters, T. M. Boland, D. EnriquezHidalgo, M. H. Deighton, M. O’Donovan, and E. Lewis. 2014. Gastrointestinal tract size, total-tract digestibility, and rumen microflora in different dairy cow genotypes. J. Dairy Sci. 97:3906-3917.

Beukes, P. C., P. Gregorini, and A. J. Romera. 2011. Estimating greenhouse gas emissions from New Zealand dairy systems using a mechanistic whole farm model and inventory methodology. Anim. Feed Sci. Technol. 166:708-720.

Broderick, G. A. 2003. Effects of varying dietary protein and energy levels on the production of lactating dairy cows. J. Dairy Sci. 86:1370-1381.

Broderick, G. A., and S. M. Reynal. 2009. Effect of source of rumendegraded protein on production and ruminal metabolism in lactating dairy cows. J. Dairy Sci. 92:2822-2834.

Burke, F., M. A. O'Donovan, J. J. Murphy, F. P. O'Mara, and F. J. Mulligan. 2008. Effect of pasture allowance and supplementation with maize silage and concentrates differing in crude protein concentration on milk production and nitrogen excretion by dairy cows. Livest. Sci. 114:325-335.

Butler, W. R. 1998. Review: Effect of protein nutrition on ovarian and uterine physiology in dairy cattle. J. Dairy Sci. 81:2533-2539.

Callis, J. 1995. Regulation of protein degradation. Plant Cell 7:845857.

Carlsson, J., J. Bergstrom, and B. Pehrson. 1995. Variations with breed, age, season, yield, stage of lactation and herd in the concentration of urea in bulk milk and in individual cows milk. Acta Vet. Scand. 36:245-254.

Castillo, A. R., E. Kebreab, D. E. Beever, and J. France. 2000. A review of efficiency of nitrogen utilisation in lactating dairy cows and its relationship with environmental pollution. J. Anim. Feed Sci. 9:1-32.

Cushnahan, A., and F. J. Gordon. 1995. The effects of grass preservation on intake, apparent digestibility and rumen degradation characteristics. Anim. Sci. 60:429-438.

De Oliveira, A. S., J. M. De Souza Campos, R. D. P. Lana, E. Detmann, and S. D. C. Valadares Filho. 2010. Estimate of the optimal level of concentrates for dairy cows on tropical pastures by using the concept of marginal analysis. R. Bras. Zootec. 39:2040-2047.

Ellis, J. L., J. Dijkstra, A. Bannink, A. J. Parsons, S. Rasmussen, G. R. Edwards, E. Kebreab, and J. France. 2011. The effect of highsugar grass on predicted nitrogen excretion and milk yield simulated using a dynamic model. J. Dairy Sci. 94:3105-3118.

Ferris, C. 2007. Sustainable pasture-based dairy systems-Meeting the challenges. Can. J. Plant Sci. 87:723-738.

Freudenberger, D. O., C. J. Burns, K. Toyokawa, and T. N. Barry. 1994. Digestion and rumen metabolism of red-clover and perennial ryegrass white clover forages by red deer. J. Agric. Sci. 122:115120. 
Gilmour, A. R., R. Thompson, and B. R. Cullis. 1995. Average information REML: An efficient algorithm for variance parameter estimation in linear mixed models. Biometrics 51:1440-1450.

Heins, B. J., and L. B. Hansen. 2012. Short communication: Fertility, somatic cell score, and production of Normande $\times$ Holstein, Montbéliarde $\times$ Holstein, and Scandinavian Red $\times$ Holstein crossbreds versus pure Holsteins during their first 5 lactations. J. Dairy Sci. 95:918-924.

Heins, B. J., L. B. Hansen, and A. De Vries. 2012. Survival, lifetime production, and profitability of Normande $\times$ Holstein, Montbéliarde $\times$ Holstein, and Scandinavian Red $\times$ Holstein crossbreds versus pure Holsteins. J. Dairy Sci. 95:1011-1021.

Home Office. 1986. Animal (Scientific Procedures) Act 1986. Her Majesty's Stationery Off., London, UK.

Huhtanen, P., E. H. Cabezas-Garcia, S. J. Krizsan, and K. J. Shingfield. 2015. Evaluation of between-cow variation in milk urea and rumen ammonia nitrogen concentrations and the association with nitrogen utilization and diet digestibility in lactating cows. J. Dairy Sci. 98:3182-3196.

Huhtanen, P., J. I. Nousiainen, M. Rinne, K. Kytola, and H. Khalili. 2008. Utilization and partition of dietary nitrogen in dairy cows fed grass silage-based diets. J. Dairy Sci. 91:3589-3599.

Huuskonen, A., P. Huhtanen, and E. Joki-Tokola. 2014. Evaluation of protein supplementation for growing cattle fed grass silage-based diets: A meta-analysis. Animal 8:1653-1662.

VSN International. 2013. GenStat for Windows. 16th ed. VSN International, Hemel Hempstead, UK.

Jiao, H. P., T. Yan, and D. A. McDowell. 2014. Prediction of manure nitrogen and organic matter excretion for young Holstein cattle fed on grass silage-based diets. J. Anim. Sci. 92:3042-3052.

Jiao, H. P., T. Yan, D. A. McDowell, A. F. Carson, C. P. Ferris, D. L. Easson, and D. Wills. 2013. Enteric methane emissions and efficiency of use of energy in Holstein heifers and steers at age of six months. J. Anim. Sci. 91:356-362.

Jonker, J. S., and R. A. Kohn. 2001. Using milk urea nitrogen to evaluate diet formulation and environmental impact on dairy farms. ScientificWorldJournal 1:852-859.

Jonker, J. S., R. A. Kohn, and R. A. Erdman. 1998. Using milk urea nitrogen to predict nitrogen excretion and utilization efficiency in lactating dairy cows. J. Dairy Sci. 81:2681-2692.

Kauffman, A. J., and N. R. St-Pierre. 2001. The relationship of milk urea nitrogen to urine nitrogen excretion in Holstein and Jersey cows. J. Dairy Sci. 84:2284-2294.

Kavanagh, S., J. Maher, L. Shalloo, and F. Kelly. F. 2003. Cost effective feeding systems for dairy cows. Pages 237-252 in Proc. Teagasc Natl. Dairy Conf. Teagasc, Dublin, Ireland.

Kebreab, E., A. B. Strathe, J. Dijkstra, J. A. N. Mills, C. K. Reynolds, L. A. Crompton, T. Yan, and J. France. 2010. Energy and protein interactions and their effect on nitrogen excretion in dairy cows. Page 417-425 in Energy and Protein Metabolism and Nutrition. 3rd EAAP Int. Symp. Parma, Italy. European Federation of Animal Science, Rome, Italy.

Lee, M. R. F., V. J. Theobald, J. K. S. Tweed, A. L. Winters, and N. D. Scollan. 2009. Effect of feeding fresh or conditioned red clover on milk fatty acids and nitrogen utilization in lactating dairy cows. J. Dairy Sci. 92:1136-1147.

Marini, J. C., and M. E. Van Amburgh. 2005. Partition of nitrogen excretion in urine and the feces of Holstein replacement heifers. J. Dairy Sci. 88:1778-1784.
McCleary, B. V., V. Solah, and T. S. Gibson. 1994. Quantitative measurement of total starch in cereal flours and products. J. Cereal Sci. 20:51-58.

Ministry of Agriculture, Fisheries and Food. 1992. Feed Composition. UK Tables of Feed Composition and Nutritive Value for Ruminants. 2nd ed. Chalcombe Publications, Nr. Canterbury, UK.

Moran, J. 2005. Milk responses to supplements. Pages 113-132 in Tropical Dairy Farming: Feeding Management for Small Holder Dairy Farmers in the Humid Tropics. Landlinks Press, Melbourne, Australia.

Nousiainen, J., K. J. Shingfield, and P. Huhtanen. 2004. Evaluation of milk urea nitrogen as a diagnostic of protein feeding. J. Dairy Sci. 87:386-398.

Owens, D., M. McGee, and T. Boland. 2008. Effect of grass regrowth interval on intake, rumen digestion and nutrient flow to the omasum in beef cattle. Anim. Feed Sci. Technol. 146:21-41.

Pareek, N., J. Voigt, O. Bellmann, F. Schneider, and H. M. Hammon. 2007. Energy and nitrogen metabolism and insulin response to glucose challenge in lactating German Holstein and Charolais heifers. Livest. Sci. 112:115-122.

Peyraud, J. L., and R. Delagarde. 2013. Managing variations in dairy cow nutrient supply under grazing. Animal 7:57-67.

Ruiz, R., G. L. Albrecht, L. O. Tedeschi, G. Jarvis, J. B. Russell, and D. G. Fox. 2001. Effect of monensin on the performance and nitrogen utilization of lactating dairy cows consuming fresh forage. J. Dairy Sci. 84:1717-1727.

Sinclair, K. D., P. C. Garnsworthy, G. E. Mann, and L. A. Sinclair 2014. Reducing dietary protein in dairy cow diets: Implications for nitrogen utilization, milk production, welfare and fertility. Animal $8: 262-274$.

Spek, J. W., J. Dijkstra, G. Van Duinkerken, W. H. Hendriks, and A. Bannick. 2013. Prediction of urinary nitrogen and urinary urea nitrogen excretion by lactating dairy cattle in northwestern Europe and North America: A meta-analysis. J. Dairy Sci. 96:4310-4322.

Stergiadis, S., X. J. Chen, M. Allen, D. Wills, and T. Yan. 2015. Prediction of metabolisable energy concentrations of fresh-cut grass using digestibility data measured with non-pregnant non-lactating cows. Br. J. Nutr. 113:1571-1584.

Thomas, T. A. 1977. An automated procedure for the determination of soluble carbohydrates in herbage. J. Sci. Food Agric. 28:639-642.

Tyrrell, H. F., and J. T. Reid. 1965. Prediction of the energy value of cow's milk. J. Dairy Sci. 48:1215-1223.

Van Der Weerden, T. J., J. Luo, C. A. M. De Klein, C. J. Hoogendoorn, R. P. Littlejohn, and G. J. Rys. 2011. Disaggregating nitrous oxide emission factors for ruminant urine and dung deposited onto pastoral soils. Agric. Ecosyst. Environ. 141:426-436.

Van Soest, P. J., J. B. Robertson, and B. A. Lewis. 1991. Methods for dietary fiber, neutral detergent fiber, and non-starch polysaccharides in relation to animal nutrition. J. Dairy Sci. 74:3583-3597.

Whelan, S. J., K. M. Pierce, C. McCarney, B. Flynn, and F. J. Munigan. 2012. Effect of supplementary concentrate type on nitrogen partitioning in early lactation dairy cows offered perennial ryegrass-based pasture. J. Dairy Sci. 95:4468-4477.

Zou, C. X., F. O. Lively, A. R. G. Wylie, and T. Yan. 2016. Estimation of the maintenance energy requirements, methane emissions and nitrogen utilization efficiency of two suckler cow genotypes. Animal 10:616-622. 